\title{
EXPERIMENTAL INVESTIGATION OF DUAL BIODIESEL BY USING VCR ENGINE
}

\author{
MUTHULURU RAJESH ${ }^{1}$, Y.V. HANUMANTHA RAO ${ }^{2}$, \\ P.S. SRINIVAS ${ }^{3} \&$ SRINIVAS PRASAD SANAKA ${ }^{4}$ \\ ${ }^{I}$ Assistant Professor, Mechanical Engineering, V.R. Siddhartha Engineering College, Vijayawada, India \\ ${ }^{2}$ Professor, Mechanical Engineering, K.L.E.F. University, Vaddeswaram,, India \\ ${ }^{3}$ Professor, Mechanical Engineering, PSCMR College of Engineering \& Technology, Vijayawada, India \\ ${ }^{4}$ Professor, Mechanical Engineering, V.R. Siddhartha Engineering College, Vijayawada, India
}

\begin{abstract}
Experiments were conducted in this study using dual biodiesels with a combination of Pongamia (Leguminosae) and Lemongrass biodiesels (cymbopogoncitratus). They are the combination with diesel at different blends ratio (P15L5, P10L10 and P5L15). The performance of dual biodiesel used in engine and exhaust gas emissions were observed in a single cylinder, direct injection, water cooling and VCR compression ignition at different loads with respect to engine speed. The performance of B20 (i.e. Pongamia 5\%, Lemongrass $15 \%$ and Diesel $80 \%$ ) was improved by 28.67\% than diesel engine and better combustion of blend was found than diesel. The emission of carbon monoxide is $18.5 \%$ decreased, hydro carbon is $16.6 \%$ decreases and carbon dioxides is $2.64 \%$ decreases of dual biodiesel blends were better than that of diesel
\end{abstract}

KEYWORDS: Blends, Compression ratio,Dual biodiesel, Emission, Lemongrass\&Pongamia

Received: May 19, 2020; Accepted: Jun 09, 2020; Published: Jun 29, 2020; Paper Id.: IJMPERDJUN2020123

\section{INTRODUCTION}

The demand for bio diesel used in automobiles increased due to the several advantages of bio diesel from its performance and emission characteristics point of view. Furthermore, the inadequate replacement of the relic fuels has affected the consideration of investigators for substitute fuel which can be formed from renewable energy. From the biodiesel as the latest encouraging substitute is presently produced from usually developed vegetable oils, such as rice bran, coconut, sunflower and palm oils [1].The Indian Railways is using 5\% biodiesel running on diesel engine trains and to attain this different biodiesels are presence experienced for their emission and performance analysis [2].From the ministry of Indian Railways evidently consume more than 1980 million liters of diesel per annual. The center ministry also presented that a slight decrease in its diesel depletion complete combination of biodiesel can generate significant saving in its diesel price with profits of domestic atmosphere due to small quantity carbon emissions. From India rule on biodiesels by advises a suggestive goal of blend $20 \%$ biodiesel combination by the future plan. However, the different methods tested by the students work on giving better result to apply additional element of exchanging biodiesel in the available diesel engine [3].Preeminent of the biodiesel commonly afford better performance and emission characteristic results presented that in some cases in oxides of nitrogen emission increases and hydrocarbon and carbon monoxide emissions reduced [4].Jindal et al. [5] disused the things of the VCR diesel engine the maximum performance characteristics is reached by the engine for injection pressure increases with maximum compression ratio and at which performance improves by $9.8 \%$ with respect to emission characteristics rise in compression ratio leads to rise in exhaust gas temperature, hydrocarbon, carbon monoxide 
,smoke decreases. Muralidharan et al. [6] studied the brake thermal efficiency and concluded the blend with unwanted cooking oil $40 \%$ is rather higher than diesel at maximum compression ratio. A.Sanjid et al. [7] compared the mustard biodiesel properties with possible biofuel properties. As a suggestion, mustard biodiesel 10\% and $20 \%$ can be utilised in diesel engine. Promote investigation can be passed out to evaluate smoke and emissions of mustard biodiesel combinations. K.Srinivas et al. [8] considered the performance and emissions characteristic with palm kernel and eucalyptus oil combination has been selected. Tests were conducted with blends and diesel on VCR engine for reasonable analysis with maximum compression ratio and increased injection pressure to 220 . The test on biofuels was carried out in computer based different compression ratio test setup at different loads. This investigation shows the reduced emissions and improved combustion for the palm kernel $85 \%$ and eucalyptus oil 15\% blend with diesel. V. Hariram and R. Vageshshangar [9] in this study, VCR engine has been recognized on decreases in compression ratios of at different loads. Rise in exhaust gas temperatures and reduction in performances and were experimental when compression ratio was decreases from 18:1 to 16:1. Decrease in cylinder pressure was detected with decrease in compression ratio. S V Channapattana et al [10] based on the experimental studies on Honne biodiesel without any engine modification. Further higher injection pressures at compression ratio of 18, appropriately decreased the emission levels was observed for the various biofuels. The nitrogen oxide emissions increase with increase in injection pressure. The NOx emissions significantly raised as the blend proportion are increased. From the honne biodiesel $20 \%$ blend results enhanced thermal performance compared to further blend, but it also leads higher levels of exhaust emissions. S. Nagaraja et al. [11] from the observation of this study has been identified that the palm oil $20 \%$ combination presented good performance and emission analysis than further combinations and diesel at maximum compression ratio at full load condition. This analysis provided the suggestion that lesser percentages of preheated palm biodiesel can be replaced as diesel. P. Shanmughasundaram [12] concluded with his experimental results that the $\mathrm{CO}$ and $\mathrm{HC}$ emissions were reduced with increase in the injection pressures \&compression ratio, while the exhaust nitrogen oxide emission improved with the rise in the injection pressure and compression ratio. The calculated model calculations can be used completely to expect the carbon monoxide, hydrocarbon, and nitrogen oxide emissions to the satisfactory level of correctly. On a normal, the carbon monoxide emissions of B20 was decreased by $48 \%$ and hydrocarbon emissions were reduced by $32 \%$ than diesel with the injection pressure of $180 \mathrm{bar}$ and at maximum compression ratio. Finally, it was concluded that 20 percent biodiesel combination could be used as biofuel in a diesel engine for lower carbon monoxide and hydrocarbon than diesel emissions. Senthilramalingam[13] examined the effect of injection pressure on the performance and emission features of diesel engine using (A20 to A100) Annona blends. The increase in injection pressure, the brake thermal efficiency is lesser than the diesel and provides a decrease in smoke, carbon monoxide and hydrocarbon emissions with an increase of NOx than the diesel. His results proven that an increase of injection pressure lowers exhaust gas emissions and substantialrisein BTE. K. Srithar et al. [14] conducted experiments with two biodiesels from mustard and Pongamia oil and they are mixed with diesel at different blend ratios. The brake thermal efficiency of Pongamia 10\% and mustard oil 10\% blend given better performance compared with diesel.

\section{BIODIESEL PRODUCTION}

The biodiesel production process is depicted in Figure 1.One of the process of converting fresh oil into biodiesel is called Transesterification. This process is shown in Fig .2 In this process, raw pongamia oil is taken as a raw oil to produce a useful biodiesel. The components used in this process are: a) Pongamia oil -1000 ml b) Methanol-200 ml c) KOH-6.5 gm. First $1000 \mathrm{ml}$ of crude Pongamia oil is taken into a glass beaker and it is placed on a heater. Then by using heater 
Pongamia oil is heated up to $100^{\circ} \mathrm{C}$ to remove the impurities existing in the Pongamia oil and after heating the oil is cooled to $60^{\circ} \mathrm{C}$ which is standard temperature for the process. Then in another beaker, $200 \mathrm{ml}$ of methanol is taken and $6.5 \mathrm{gm}$ of $\mathrm{KOH}$ is added to this methanol. Blend of methanol and $\mathrm{KOH}$ is poured into raw oil at $60^{\circ} \mathrm{C}$.Then a lid is placed on container which contains raw oil at $60{ }^{\circ} \mathrm{C}$ and dissolved $\mathrm{KOH}$ in methanol. Then a magnetic stirrer is placed in beaker on heater. Stir the mixture with $1200 \mathrm{rpm}$ by maintaining at $55^{\circ} \mathrm{C}-60^{\circ} \mathrm{C}$ till 150 minutes $(2.30 \mathrm{hrs})$.

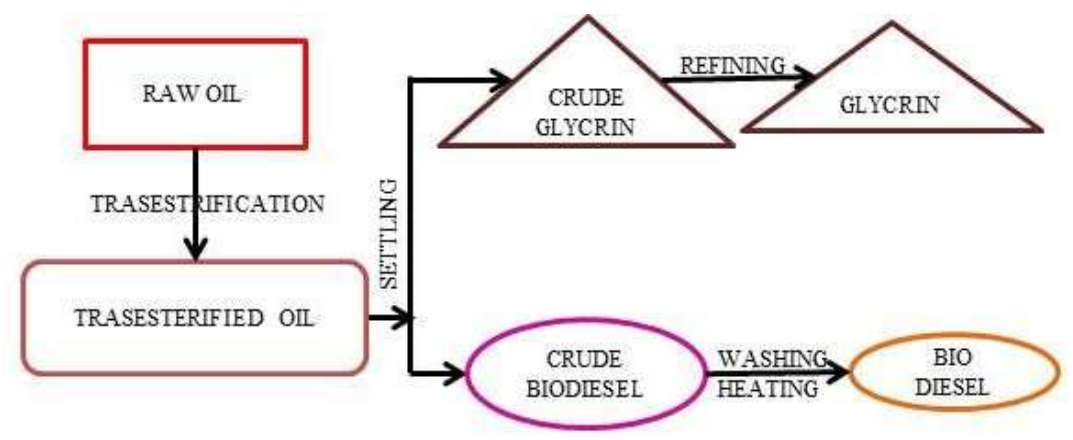

Figure 1: Flow chart for Biodiesel Production.

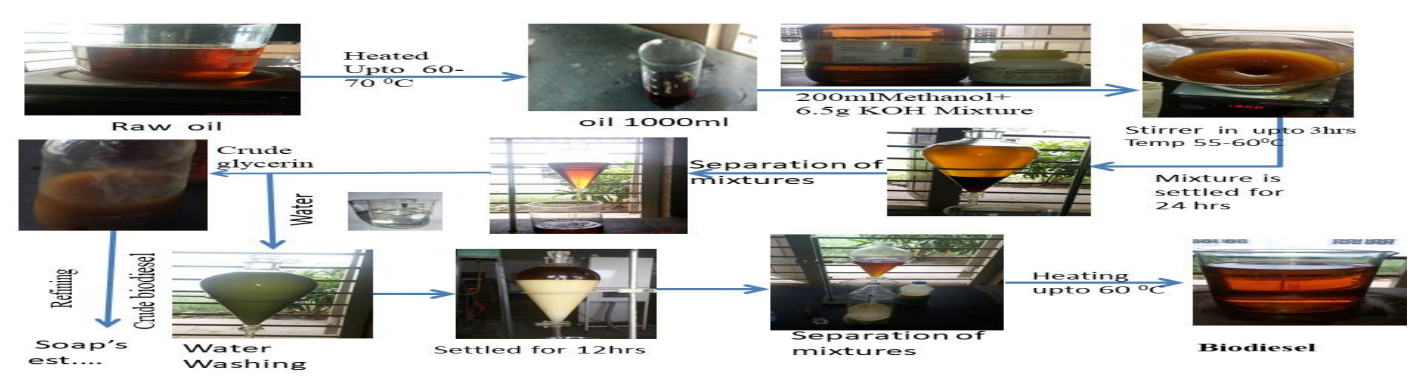

Figure 2: Transestrification Biodiesel Process.

Then, switch off the heater and allowed to cool. Pour the mixture after cooling into a funnel and leave the mixture in a stable position for $24 \mathrm{hrs}$ to settle. After $24 \mathrm{hrs}$ we get two layers in the funnel. Upper portion is crude biodiesel and bottom portion is crude glycerin. Drain off the glycerin and crude biodiesel and water more than $50 \%$ of crude biodiesel is poured in a bottle. Then shake the bottle and this mixture is poured in to funnel again. Allow to leave this mixture in funnel for 18-20 hrs to settle. Again, two layers are formed in the funnel. Upper portion is oil and bottom portion is crude. Refined Pongamia Bio diesel produced is collected and heated up to $45^{\circ} \mathrm{C}-55^{\circ} \mathrm{C}$. The refined lemongrass oil has been collected from market to conduct experiments with dual biodiesel mixed with diesel.

\section{Biodiesel Blends Preparation}

Blends were prepared in different proportions of Pongamia, lemongrass oils and diesel P15L5, P10L10 and P5L15 maintaining constant blend ratio B20. The various properties of tested fuels like mass density, kinematic viscosity, heating value, flash and fire point were calculated by using ASTM methods. The mixed blends appearances presented that kinematic viscosity of the blends increased with biodiesel quantities. The dual biodiesel and diesel description is given below in Table.1. The viscosity was higher for dual biodiesels and lower for diesel. The density of the mixed blends (i.e. P15L5, P10L10 and P5L15) showed a commonly in relation to an increase in blends proportion. It was told that lower heating value of mixed dual biodiesels is due to longer oxygen satisfied than relate to diesel. Form the higher viscosity and density of blends are due to their complicated chemical structure and higher molecular weight. 

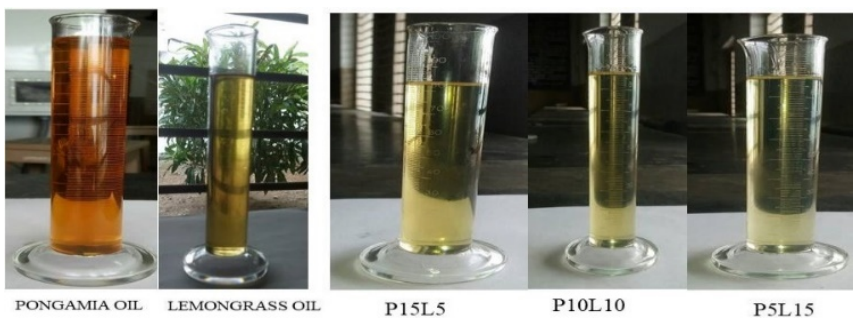

Figure 3: Dual Biodiesels of Mixed Ratios.

Table 1: Properties of Fuels

\begin{tabular}{|c|c|c|c|c|c|c|}
\hline Properties & Diesel & $\begin{array}{c}\text { P15l5 } \\
\text { d80 }\end{array}$ & $\begin{array}{l}\text { P10110 } \\
\text { d80 }\end{array}$ & $\begin{array}{c}\text { P5I15 } \\
\text { d80 }\end{array}$ & $\begin{array}{c}\text { PongamiaMethyl } \\
\text { EsterPb100 }\end{array}$ & $\begin{array}{c}\text { Lemongrass } \\
\text { MethylEster } \\
\text { Lb100 } \\
\end{array}$ \\
\hline Density $\mathrm{kg} / \mathrm{m}^{3}$ & 820 & 834 & 835 & 835 & 890 & 890 \\
\hline $\begin{array}{c}\text { Viscosity @ 40 } \\
\text { Cst }\end{array}$ & 2.8 & 3.17 & 3.14 & 3.12 & 4.66 & 4.35 \\
\hline $\begin{array}{c}\text { Calorific value } \\
\mathrm{MJ} / \mathrm{kg}\end{array}$ & 42.5 & 41.19 & 41.20 & 41.22 & 35.86 & 36.23 \\
\hline Flash point ${ }^{0} \mathrm{C}$ & 58 & 71 & 70 & 69 & 130 & 115 \\
\hline Fire point ${ }^{0} \mathrm{C}$ & 66 & 78 & 76 & 75 & 142 & 126 \\
\hline
\end{tabular}

\section{Experimental setup}

The experimental setup used is a computer based four stroke, single cylinder, water cooled system, VCR direct injection diesel engine. This engine analysis software is lab vision based software established by TECH-ED for estimation of performance and emission features of the given VCR experimental setup shown in Fig 4 and Figure 5.

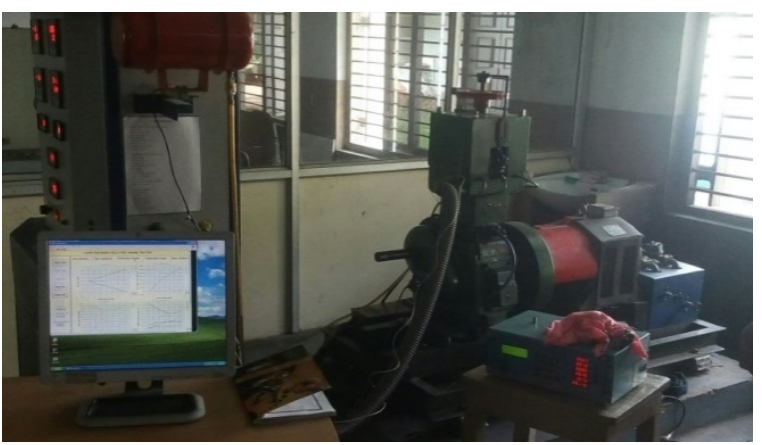

Figure 4: Experimental Setup

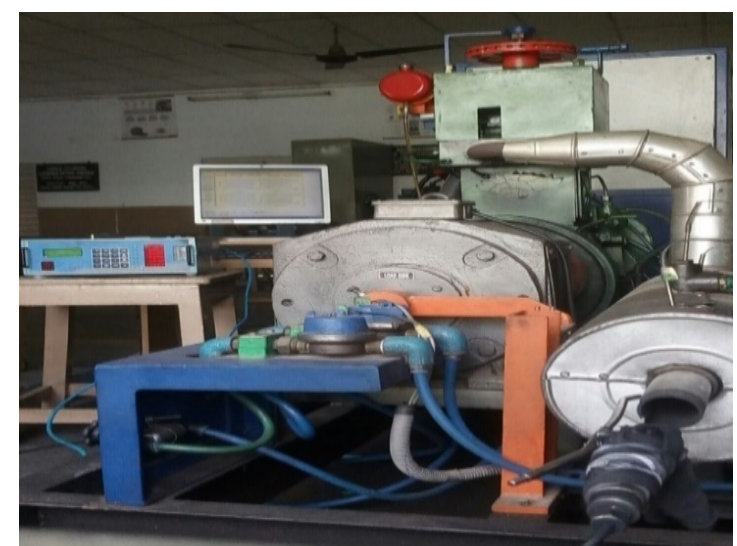

Figure 5:Experimental Setup 
Table 2: VCR Engine used for Experiments

\begin{tabular}{|l|l|}
\hline \multicolumn{1}{|c|}{ Items } & \multicolumn{1}{c|}{ Description } \\
\hline Model & $\begin{array}{l}\text { Kirloskar VCR } \\
\text { engine }\end{array}$ \\
\hline Type & $\begin{array}{l}4 \quad \mathrm{~S}, \\
\text { cylinder }\end{array}$ \\
\hline Cooling System & Water cooled \\
\hline Bore diameter & $80 \mathrm{~mm}$ \\
\hline Stroke & $56 \mathrm{~mm}$ \\
\hline Compression ratio & 12 to 20 \\
\hline Rated Speed & $\begin{array}{l}\text { Fifteen Hundred } \\
\text { rpm }\end{array}$ \\
\hline Rated Power & $\begin{array}{l}3.7 \\
(5 \mathrm{HP})\end{array}$ \\
\hline
\end{tabular}

\section{RESULTS AND DISCUSSIONS}

The tests conducted at the full load condition at injection pressure of 220 bar, at Compression ratio (CR19.5:1) for the dual biodiesels blends, diesel (i.e. P15L5D80, P10L10D80,P5L15D80). The results obtained from the tests such as the performance and emissions data, brake thermal efficiency, bsfc, carbon monoxide, $\mathrm{HC}, \mathrm{CO}_{2}$ and nitrogen (NOx) are plotted against loads.

\section{Performance Analysis}

The brake thermal efficiency (BTE) characteristics against load have been plotted for various mixed blends are shown in Fig 6. It was evident that the BTE of biodiesel is higher than compare to diesel particularly for full load condition. From the graph it is evident that the BTE has enhanced with increase in blend ratio of biodiesel. BTE of mixed blends for P15L5, P10L10 , P5L15 are 21.8 (12.08\%), 24.83 (27.6\%) and 25.4 (30.59\%) respectively higher than diesel (19.45). The blends heating value is lower than the diesel. The mixing process enabled the quality combustion. Therefore, BTE of dual biodiesel with P5 L15 is higher than diesel at full load.

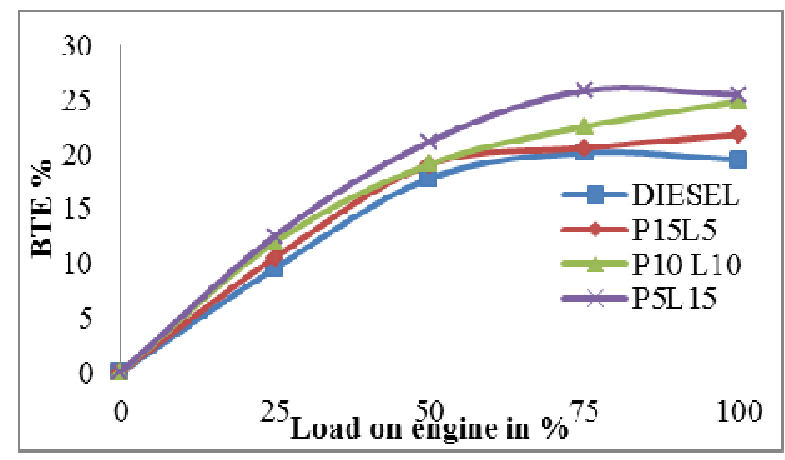

Figure 6 Variation of BTE with load 


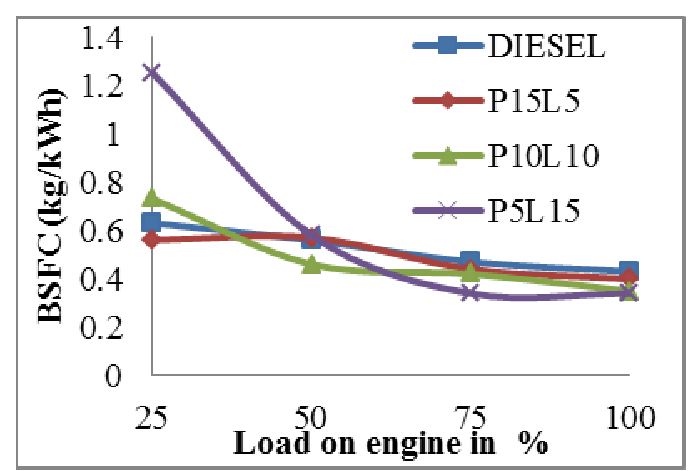

Figure 7: Variation of BSFC with load

The bsfc with different blends is lowered than diesel at Full load and it is shown in Figure 7. The bsfe reduced for the dual biodiesels at different mixed blends ratio. At the full load condition, compression ratio of 19.5, the value of bsfcfor mixed blends ratio B20 in P15L5, P10L10,P5L15 is $0.4,0.35,0.34 \mathrm{~kg} / \mathrm{kW}$ h whereas diesel have $0.43 \mathrm{~kg} / \mathrm{kW}$ h. The higher bsfc indicates that the dual biodiesel fuel consumption is high due to the heating value of the mixed blends is lower than Diesel.

\section{Combution Analysis}

The difference of pressure variation with varying crank angle for the various blend ratio is shown in Figure 8.The combustion pressure has been observed that the blends ratio are higher than compare with diesel. The blends ratio may be due to quickly and better combustion characteristics. The amount of heat is absorbed on blend from the cylinder proximately later fuel injection and results in maximum combustion pressures. The combustion pressures are P5L15 given 64.2, P10L10 given 68.43 and P5L15 given71.77 than diesel.

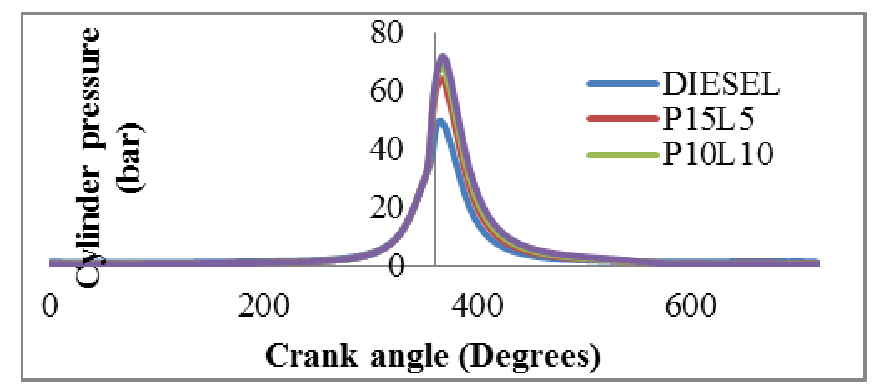

Figure 8: Variation of Combustion Pressure with Crank Angle.

\section{Effect of Heat Release Rate}

The difference of heat release rate with respects to crank angle for the variation blends ratio is shown in Figure 9. From the heat release rate is analysis based on cylinder the crank angle for full load condition. It can be due to the fuel atomization and vaporization of blends ratio from the better spray formation inner the combustion chamber. The heat release rates are P15L5, P10L10 and P5L15given 40.57, 44.33 and 43.07 than diesel. 


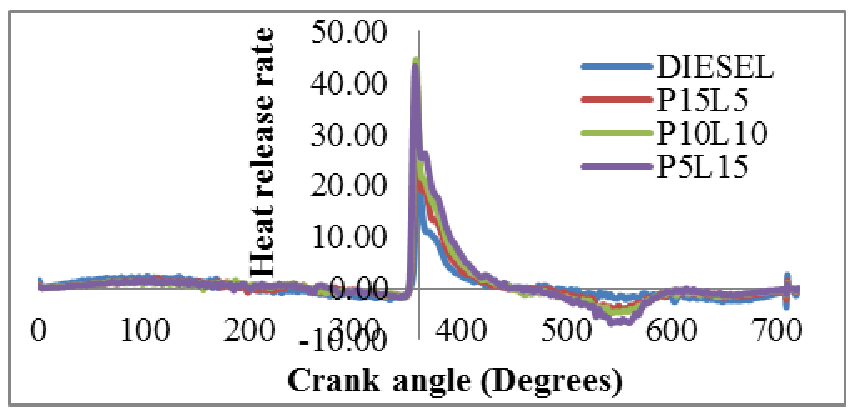

Figure 9: Variation of Heat Release Rate with Crank Angle.

The heat release rate at different crank angle for various blend ratios is shown in above Figure 9. From the heat release rate is plotted for full load condition for various blend ratios. It can be due to the fuel atomization and vaporization of blends ratio from the better spray formation inner the combustion chamber. The heat release rates are P15L5, P10L10 and P5L15given 40.57, 44.33 and 43.07.

The percentage of carbon monoxide (CO) with varying load is shown in Fig 10. The graph shows that, as load increases the \% of $\mathrm{CO}$ also raised. From the carbon monoxide dual biodiesels combined blends ratio B20 (that is .P15L5, P10L10, P5L15) decreases than diesel for full load condition in compression ratio19.5 (CR19.5:1), the value of carbon monoxide (CO) for combined Blends ratio B20 in P15L5 is 3.26\%, P10L10 with 4.67\% ,P5L15 having 4.26\% while diesel has $5.23 \%$.

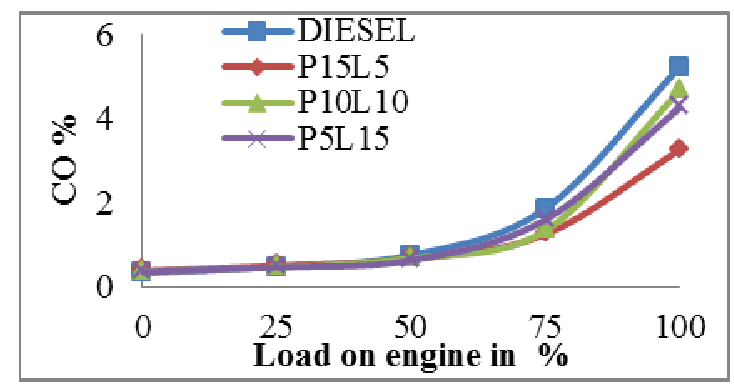

Figure 10: Variation of CO with load.

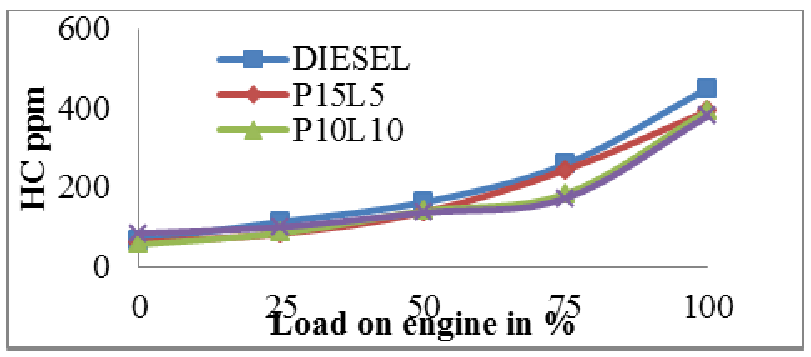

Figure 11: Variation of HC with Load.

Variation of HCwith varying load is shown in Figure 11 since the graph identified that as the load increases the HC raised. The HC of dual biodiesel combined blends ratioB20 (that is P15L5, P10L10 and P5L15) decreases than diesel for full load condition in compression ratio19.5 (CR19.5:1), the value of HC for combined blends ratio B20 in P15L5 is 393 parts per million, P10L10 with 393 ppm \& P5L15 has 380 while diesel has 456. The emission reduced with increase in amount of dual biodiesel from $16.6 \%$ reduces in hydro carbon. 


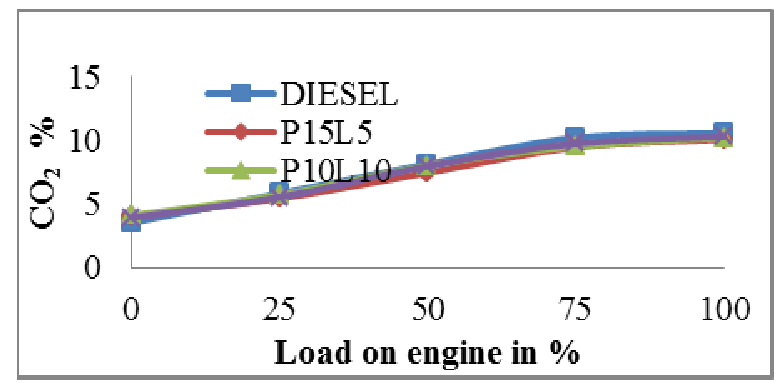

Figure 12: Variation of $\mathrm{CO}_{2}$ with Load.

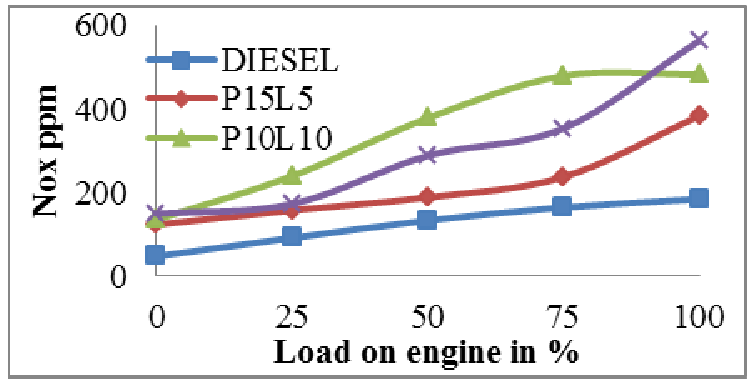

Figure 13: Variation of NO with load.

The change of carbon dioxide $\left(\mathrm{CO}_{2}\right)$ with varying load is depicted in Figure 12, since the graph identified that as the load increases the carbon dioxide raises. The $\mathrm{CO}_{2}$ fordual biodiesel combinedblends ratio B20 (that is P15L5, P10L10 \& P5L15) decreases than diesel for full load condition. $\mathrm{CO}_{2}$ is formed when there is required sum amount of oxygen content existing through formation of carbon monoxide particle as combustion product. In the lower dual biodiesel combined blends ratio B20, P15L5, P10L10 \& P5L15 showed average 2.64\% decrease in compare with diesel.

The variation of NO with varying load is depicted in Figure 13. The NOxraised at all loads for each combined blends ratio B20 (that is P15L5, P10L10 \&P5L15). For the compression ratio 19.5 at maximum load condition, mixed blends ratio P15L5 gave 384 parts per millionwhile diesel has 211 ppm, P10L10 shows 483, and P5L15 indicates 564 at the full load. As per results, NOx emission is greater for combined blends ratio than diesel. However, the nonedible oil based biodiesel contains a little bit amount of nitrogen.

\section{CONCLUSIONS}

Effects of compression ratio on a single cylinder VCR diesel engine features run by dual biodiesels B20 blend ratios (that is P15L5, P10L10 and P5L15) were investigated. Important outcomes are summarized below. BTE and bsfc of B20 blend ratios (i.e. P15L5, P10L10 and P5L15) was slightly higher than the diesel. Dual biodiesels blend B20 blend ratios showed the carbon monoxide, hydro carbons, carbon dioxide and nitrogen oxides emissions in comparison to diesel. The carbon monoxide (CO), hydro carbons ( $\mathrm{HC}$ ), and carbon dioxide ( $\mathrm{CO} 2)$ emissions were further reduced, but will be nitrogen oxides (NOx) emissions increases. Overall, this experimental analysis suggested that utilization of dual biodiesels blend B20 combined ratios (i.e. P15L5, P10L10 and P5L15) in VCR diesel engine at compression ratio 19.5 can be worthwhile in enriching the performance with lower exhaust gas emissions.

\section{REFERENCES}

1. Takase, Mohammed, Ting Zhao, Min Zhang, Yao Chen,Hongyang Liu, Liuqing Yang, and Xiangyang Wu.. "An Expatiate Review of Neem, Jatropha, Rubber and Karanja as Multipurpose Non-Edible Biodiesel Resources and Comparison of their Fuel, Engine and Emission Properties” Renewable \& Sustainable Energy Reviews 43: p.495-520., 2015 
2. Nalgundwar, A., Paul, B. and Sharma, S.K. "Comparison of performance and emissions characteristics of DI CI engine fueled with dual biodiesel blends of palm and jatropha”. Fuel, 173, pp.172-179, 2016.

3. Rao, P.S. and Srinivas, K., "Experimental Analysis Of Single Cylinder Diesel Engine Fuelled With Methyl Ester Of Palm Kernel Oil Blending With Eucalyptus Oil. International Journal of Engineering Research and Applications”, 2, pp.90-95, 2012.

4. Ashraful, A.M., H. H. Masjuki, M. A. Kalam, I. M. Rizwanul Fattah, S. Imtenan, S. A. Shahir, and H. M. Mobarak. "Production and Comparison of Fuel Properties, Engine Performance, and Emission Characteristics of Biodiesel from VariousNon-Edible Vegetable Oils: A Review.” Energy Conversion and Management 80: 202-228, 2014

5. S. Jindhal, B.P. Nandwana, N.S. Rathore, V. Manistha, "Experimental Investigation of the effect of compression ratio and injection pressure in a direct injection diesel engine running on Jatropha methyl ester", Appl. Therm. Eng. Pp 442-448, 2010

6. K. Muralidharn, D. Vasudevan, "Performance, emission and combustion characteristics of a variable compression ratio engine using esters of waste cooking oil and diesel blends”, Appl. Energy 88, 3959-3968, 2011

7. Sanjid, A., Masjuki, H.H., Kalam, M.A., Abedin, M.J. and Rahman, S.A.," Experimental investigation of mustard biodiesel blend properties,performance, exhaust emission and noise in an unmodified diesel engine". APCBEE procedia, 10, pp.149153, 2014.

8. Banoth, B.N. and Kadavakollu, K.R."Performance and Emission of VCR-CI Engine with palm kernel and eucalyptus blends" Perspectives in Science, 8, pp.195-197, 2016.

9. Hariram, V. and Shangar, R.V. Influence of compression ratio on combustion and performance characteristics of direct injection compression ignition engine. Alexandria Engineering Journal, 54(4), pp.807-814, 2015.

10. Channapattana, S.V., Pawar, A.A. and Kamble, P.G.,. "Effect of injection pressure on the performance and emission characteristics of VCR engine using honne biodiesel as a fuel". Materials Today: Proceedings, 2(4-5), pp.1316-1325, 2015.

11. Nagaraja, S., Sooryaprakash, K. and Sudhakaran, R."Investigate the effect of compression ratio over the performance and emission characteristics of variable compression ratio engine fueled with preheated palm oil-diesel blends". Procedia earth and planetary science, 11, pp.393-401, 2015.

12. Shanmughasundaram, P."Experimental investigation on the emission characteristics of a variable compression ratio multifuel engine using palm biodiesel”. International Journal of Ambient Energy, 38 (6), pp.576-581.30, 2017.

13. Ramalingam, S., Rajendran, S. and Ganesan, P." Impact of injection pressure on the performance and emission characteristics of a diesel engine fuelled with Annona methyl ester”. Biofuels, 6 (5-6), pp.295-303, 2015.

14. Srithar. K, Balasubramanian. K.A, Pavendan, V. and Kumar, B.A,. "Experimental investigations on mixing of two biodiesels blended with diesel as alternative fuel for diesel engines”. Journal of King Saud University- Engineering Sciences, 29(1), pp.50-56, 2017.

15. Sekhar, K., Rao, M. P., Naidu, T. S., \& Naidu, A. L. Performance And Emission Characteristics Of High Speed Diesel Engine Blends With Carbon Nanotubes Added Ethanol-Diesel.

16. Singh, P. Volkswagen Emissions Scandal-A Case Study Report.

17. Jayaraman, K., \&Kuppusamy, V. Effect Of Injection Pressure On A Diesel Engine Using Pyrolysis Bio-Oil From Spirulina Algae.

18. Patil, A. K., \&Ganur, S. G. Comparative Study On The Effect Of Nanoadditives With Biodiesel Blend On The Performance And Emission Characteristics Of A Laboratory Ci Engine. 


\section{AUTHOR'S PROFILE}

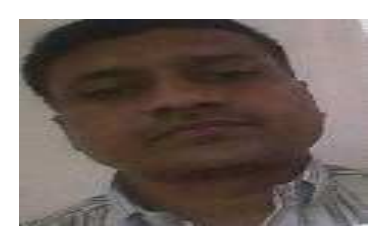

Mr. Muthuluru Rajesh, Assistant Professor is a research scholorin Mechanical Engineering from KLEF University, Vaddeswaram.The areas of interests are IC Engines and Alternate Fuels. 4 papers have been published in reputed Journals

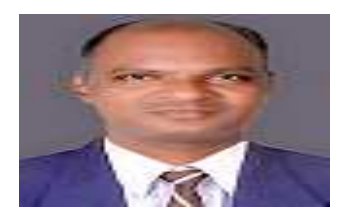

Dr. Y.V.HanumanthaRao, Professor completed doctorate in Mechanical Engineering from JNTU Kakinada in 2010. The areas of interests are Heat Transfer, IC Engines,Thermo dynamics. 30 papers have been published in reputed Journals

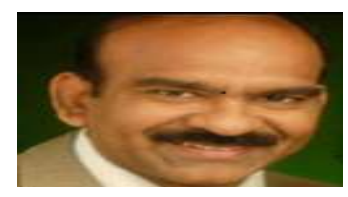

Dr.P.S.Srinivas, Professor completed doctorate in Mechanical Engineering from JNTU Kakinada in 2013. The areas of interests are CFD, Robotics, CAD/CAM, and Production Engineering.40 papers have been published in reputed Journals

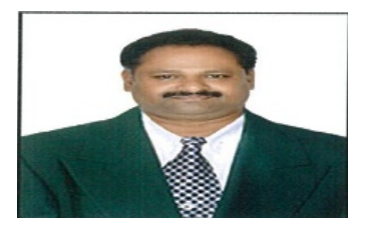

Dr. Srinivas Prasad Sanaka, Professor completed doctorate in Mechanical Engineering from Osmania University in 2013 and Masters from NIT Bhopal. The areas of interests are CFD, Heat Transfer, Turbo Machinery, High Speed flows. 54 papers have been published in reputed Journals 